\title{
Chitinase-3-Like Protein 1
}

National Cancer Institute

\section{Source}

National Cancer Institute. Chitinase-3-Like Protein 1. NCI Thesaurus. Code C93267.

Chitinase-3-like protein 1 (383 aa, $43 \mathrm{kDa}$ ) is encoded by the human CHI3L1 gene. This protein plays a role in tissue remodeling, inflammation and chitin binding. 